\title{
PENGELOLAAN KEUANGAN PONPES DALAM RANGKA PENINGKATAN MASYARAKAT MANDIRI DI PANTI ASUHAN IKHWANIYAH CINTA YATIM DAN DHUAFA
}

\author{
${ }^{1}$ Priehadi Dhasa Eka, ${ }^{2}$ Randhy Agusentoso, ${ }^{3}$ Suwanto, ${ }^{4}$ Hafis Laksmana Nur \\ Aldy, ${ }^{5}$ Muhammad Gandung \\ Dosen Fakultas Ekonomi Universitas Pamulang \\ Email : 1. dosen01577@unpam.ac.id
}

\begin{abstract}
ABSTRAK
Pengabdian yang dilakukan adalah pelatihan pengelolaan keuangan ponpes dalam rangka peningkatan masyarakat mandiri di PA Ikhwaniyah Cinta Yatim dan Dhuafa. Oleh karena itu pengabdian ini berfokus pada peningkatan kemampuan pengelolaan keuangan ponpes melalui pelatihan pengelolaan keuangan. Selain itu, kegiatan pengabdian ini juga memiliki tujuan untuk mendukung program pemerintah melalui Otoritas Jasa Keuangan (OJK) dalam perencanaan keuangan ponpes.

Adapun sasaran pada pengabdian masyarakat ini adalah warga di ponpes dalam rangka peningkatan masyarakat mandiri di PA Ikhwaniyah Cinta Yatim dan Dhuafa. Program pengabdian ini dilaksanakan selama kurun waktu 3 hari. Metode yang digunakan dalam pengabdian ini adalah pelatihan dan juga pendampingan tentang pengelolaan keuangan ponpes.

Hasil pengabdian ini menunjukkan bahwa warga ponpes sangat antusias mengikuti pelatihan pengelolaan keuangan. Lebih lanjut, dengan dilaksanakannya kegiatan pengabdian ini, masyarakat khususnya warga ponpes memiliki kemampuan untuk mengelola keuangan rumah tangga sesuai dengan program pemerintah. Selain itu, kegiatan ini juga mampu memberikan dukungan agar ponpes terhundar dari pihak pihak yang tidak di inginkan. Untuk kegiatan pengabdian selanjutnya diharapkan mampu memberikan pelatihan yang berkelanjutan yang memicu semangat warga ponpes untuk menghasilkan pendapatan sendiri demi meningkatkan kesejahteraan kehidupan warga ponpes.
\end{abstract}

\section{Kata Kunci : Pengelolaan Keuangan; Unit Usaha, Kapasitas, Pondok Pesantren}

\section{PENDAHULUAN}

Beberapa penelitian terkait pengembangan pesantren melalui pengelolaan pendanaan, antara lain : (Azizah, 2014) dalam penelitiannya mengenai pengelolaan unit usaha pada pesantren, mengatakan bahwa proses manajemen unit usaha ekonomi di Pondok Pesantren serta pengembangannya memiliki dampak positif untuk mencapai kesejahteraan bersama, yaitu ; a) terciptanya pola kader umat (santri dan masyarakat) yang mandiri dalam bidang ekonomi, b) terbentuknya pesantren yang mandiri dalam bidang ekonomi, c) menjadikan pesantren sebagai 
patner pemerintah, dan d) mampu mengangkat ekonomi umat (ekonomi masyarakat sekitar pesantren maupun masyarakat secara luas). (Rifqi, 2014) dengan penelitian tentang strategi pembiayaan mandiri pondok pesantren, mengatakan bahwa sumber pembiayaan pesantren berasal dari antara lain : peserta didik, pemerintah, sumbangan BMT-UGT, BMT Maslahah, dan usaha kreatif pesantren. Akan tetapi usaha kreatif merupakan bentuk dari pembiayaan yang bersifat mandiri bagi pondok pesantren, yang dapat digunakan untuk mengatasi permasalahan terkait ketidakpastian pendanaan yang diperoleh dari uang pembayaran santri atau peserta didik.

\section{METODE PELAKSANAAN KEGIATAN}

Upaya dalam meningkatkan independensitas pondok pesantren tersebut, yaitu melalui pengembangan lembaga usaha mikro dalam lingkungan pondok pesantren. Hal ini disebabkan, karena pondok pesantren tidak ingin bergantung pada kucuran dana pemerintah, akan tetapi lebih menghidupkan potensi usaha mikro keuangan yang dimiliki oleh pondok pesantren. Apabila lembaga keuangan mikro ini dikembangkan, maka dapat menunjang terpenuhinya kebutuhan dalam mengelola pondok pesantren, sekaligus dapat menghidupkan pula pedagangpedagang di sekitarnya.

Untuk dapat memenuhi kebutuhan tersebut, maka ada beberapa strategi yang dilakukan oleh pondok pesantren tersebut. Strategi ini dilakukan dalam upaya untuk meningkatkan pendapatan pondok pesantren, sehingga kebutuhan-kebutuhan terhadap biaya-biaya rutin, seperti : biaya listrik, biaya air, biaya peralatan kantor serta biaya penunjang kegiatan belajar mengajar bisa terpenuhi. Strategi dalam meningkatkan pendapatan pondok pesantren, yaitu dengan mengembangkan unitunit usaha diantaranya toko serba ada, usaha di bidang pertanian dan tambak garam.

\section{HASIL DAN PEMBAHASAN}

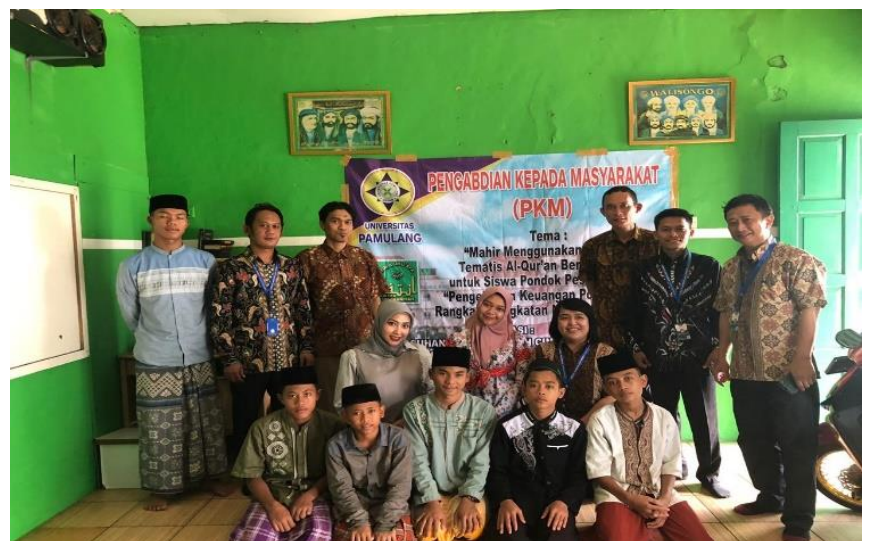

Gambar 1. Foto Bersama Ponpes Pesantren
Berdasarkan uraian yang telah dijelaskan diatas, dapat terlihat bahwa setiap pondok pesantren memiliki tekad untuk terus mengembangkan pondok pesantrennya, tanpa mengandalakan bantuan dari pihak ketiga. Untuk itu, maka kemudian diperlukan penjelasan lebih konkrit, mengenai bagaimana pengelolaan keuangan unit usaha pondok pesantren sebagai strategi pengembangan kapasitas pondok pesantren.

Inilah yang mendasari kami membentuk team PKM didalam memberikan 
informasi, petunjuk dan bimbingan serta motivasi sebagai bentuk pengejawantahan dari Tri Dharma Perguruan Tinggi dengan tema "Pengelolaan Keuangan Ponpes Dalam Rangka Peningkatan Masyarakat Mandiri” di PA Ikhwaniyah Cinta Yatim dan Dhuafa.

Metode Manajemen keuangan yang digunakan dalam pondok pesantren serta Ada tiga faktor yang berperan dalam sistem penyelenggaraan Pondok Pesantren yaitu, manajemen sebagai faktor upaya, organisasi sebagai factor Sarana, dan administrasi sebagai faktor karsa. Ketiga faktor ini memberi arah dan perpaduan dalam merumuskan, mengendalikan, penyelenggaraan, mengawasi serta menilai pelaksanaan kebijakan kebijakan dalam usaha menyelenggarakan kegiatan pendidikan yang sesuai dengan tujuan setiap Pondok Pesantren.Salah satu komponen manajemen sebagai upaya dalam pondok pesantren adalah manajemen keuangan. Manajemen keuangan pondok pesantren merupakan kegiatan yang dilakukan guna mencapai tujuan pondok pesantren yang telah direncanakan dengan mengembangkan dan mengelola sumber daya dan sumber dana serta potensipotensi yang dimiliki dalam sistem pondok pesantren secara efektif dan efisien.

Kegiatan ini dapat dimulai dari perencanaan, pengorganisasian, pelaksanaan sampai dengan pengawasan. Dalam manajemen keuangan di sekolah tersebut dimulai dengan perencanaan anggaran sampai dengan pengawasan dan pertanggung jawaban keuangan.Manajemen keuangan pondok pesantren merupakan salah satu substansi manajamen lembaga pendidikan yang akan turut menentukan kelancaran kegiatan pondok pesantren. Seperti halnya yang terjadi pada substansi manajemen pendidikan pada umumnya, kegiatan manajemen keuangan pondok pesantren seyogyanya dilakukan melalui proses perencanaan, pengorganisasian, pengarahan, pengkoordinasian, pengawasan atau pengendalian. Beberapa kegiatan manajemen keuangan berupa kegiatan memperoleh dan menetapkan sumber-sumber pendanaan, pemanfaatan dana, pelaporan, pemeriksaan dan pertanggung jawaban.

Pesantren atau Pondok Pesantren adalah salah satu pendidikan Islam di Indonesia. rekonstruksi Reformasi

pendidikan Islam beserta lembaga-lembaganya tampaknya perlu segera dilakukan, terutama mencermati perkembangan dunia global yang mengharuskan setiap lembaga pendidikan Islam untuk terus berbenah diri kalau tidak ingin

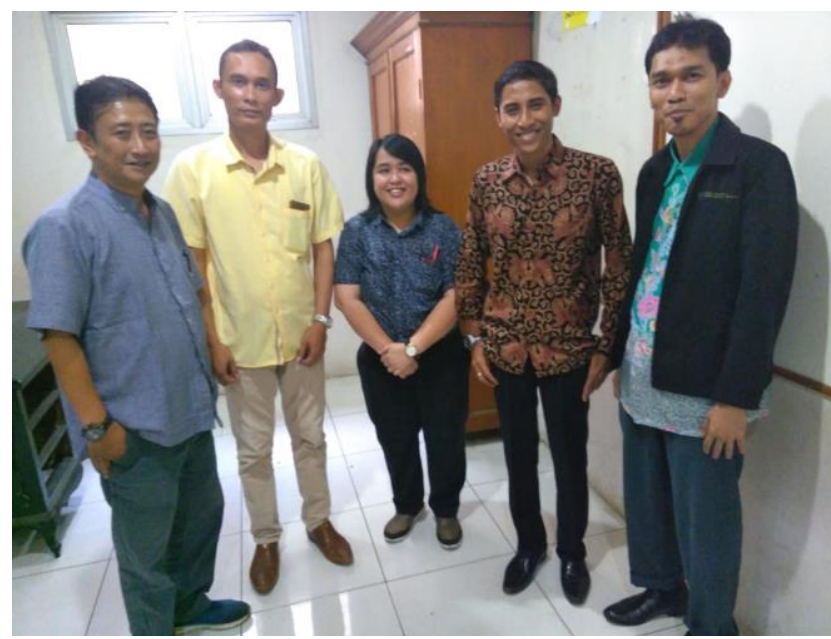

Gambar 2. Foto Sebelum Melakukan PKM ditinggalkan oleh peminatnya. Sikap inklusif dari pendidikan Islam dalamkonteks 
ini sangat diperlukan. inkIusivitas menjadi sangat penting mengingat bahwa bagaimanapun, institusi pendidikan Islam tidak mungkin mengisolisasi diiri dari dinamika yang terjadi diluar dirinya..Mulai pada paruh kedua dari abad 20, beberapa pesantren mulai menambahkan mata pelajaran sekuler dengan kurikulum mereka sebagai cara negosiasi Modernitas.Penambahan kurikulum diakui negara telah mempengaruhi pesantren tradisional dalam beberapa cara. Hal ini menyebabkan kontrol yang lebih besar oleh pemerintah nasional.

Sebagaimana diketahui Bank Indonesia bersama Kementerian Koordinator Rabu, 5 November 2014, Gubernur Bank Indonesia, Agus D.W. Martowardojo dan Menteri Agama, Lukman Hakim Saifuddin melakukan penandatanganan Nota Kesepahaman mengenai Pengembangan Kemandirian Ekonomi Lembaga Pondok Pesantren dan Peningkatan Layanan Non Tunai untuk Transaksi Keuangan di Lingkungan Kementerian Agama, bertempat di Surabaya. Penandatanganan kerjasama tersebut merupakan salah satu rangkaian acara Indonesia Sharia Economic Festival (ISEF) yang berlangsung sejak tanggal 3 sampai dengan 9 November 2014 di Surabaya.

Sebelum kegiatan penandatanganan tersebut diselenggarakan acara "Bincang Nasional Pemberdayaan Pesantren dalam Rangka Peningkatan Kemandirian Ekonomi serta Mendorong Pengembangan Ekonomi dan Keuangan Syariah" yang juga dihadiri oleh Gubernur Bank Indonesia, Menteri Agama, Ketua Otoritas Jasa Keuangan, Gubernur Jawa Timur, tokoh agama, pengasuh pondok pesantren, pejabat Kementerian Kebudayaan dan Pendidikan Dasar dan Menengah, serta pejabat Kementerian Agama Pusat dan Propinsi se-Indonesia Pengasuh Pondok Pesantren yang mengembangkan perekonomian mandiri.

Kerjasama yang dijalin kedua lembaga ini bertujuan untuk meningkatkan kapabilitas dan keterampilan lembaga pondok pesantren melalui pemberian bantuan teknis antara lain berupa pelatihan dan pendampingan kelembagaan, pencatatan dan pengelolaan keuangan serta kemampuan kewirausahaan para santri, dan meningkatkan akses keuangan pada lembaga pondok pesantren antara lain melalui kegiatan edukasi. Selain itu kerjasama ini juga ditujukan untuk meningkatkan penggunaan layanan non tunai untuk transaksi keuangan di lingkungan Kementerian Agama melalui edukasi dan peran sebagai fasilitator dalam pengembangan proses bisnis.

"Implementasi Nota Kesepahaman ini untuk pertama kalinya akan dilakukan di wilayah Jawa Timur dengan pertimbangan potensi pondok pesantren yang jumlahnya kurang lebih 6.000 lembaga serta sejalan dengan rencana pemerintah untuk menjadikan Surabaya sebagai Pusat Pengembangan Ekonomi Syariah Nasional. Selanjutnya gerakan awal di Jawa Timur ini diharapkan mampu menginspirasi wilayah lain sehingga mengakselerasi inklusivitas keuangan di masyarakat," demikian disampaikan Agus D.W. Martowardojo di Surabaya.

Terdapat beberapa program yang akan didorong melalui kerjasama ini antara lain program edukasi keuangan yang bertujuan untuk meningkatkan pengetahuan para santri mengenai pengelolaan keuangan dan perbankan, pengembangan wirausaha melalui inkubator kewirausahaan di lembaga pondok 
pesantren, dan pengembangan Layanan Keuangan Digital Bidang Perekonomian, Kementerian Keuangan, Pemerintah Daerah serta Asosiasi Pemerintahan Provinsi Seluruh Indonesia pada tanggal 14 Agustus 2014 telah mencanangkan dan berkomitmen mendukung Gerakan Nasional Non Tunai (GNNT). Sejalan dengan GNNT tersebut, Pemerintah telah melaksanakan program penyaluran bantuan dalam bentuk Kartu Indonesia Sehat (KIS), Kartu Indonesia Pintar (KIP) dan Kartu Keluarga Sejahtera (KKS) pada tanggal 3 November 2014 lalu melalui LKD. Perluasan GNNT ini juga dilakukan untuk transaksi keuangan di lingkungan instansi pemerintahan. Melalui gerakan ini masyarakat didorong untuk melakukan transaksi non tunai yang diharapkan mampu mengatasi keterbatasan atau kendala ketika dilakukan secara tunai.

\section{KESIMPULAN DAN SARAN}

Dengan adanya kegiatan ini dan Kerjasama Bank Indonesia dan Kementerian Agama juga dilator belakangi oleh jumlah penduduk muslim di Indonesia yang besar. Seiring dengan hal tersebut keberadaan lembaga pendidikan juga semakin meluas, dan jumlah santri juga mengalami peningkatan. Dengan potensi yang cukup besar ini pemberian edukasi keuangan kepada para santri dapat mendorong kemandirian ekonomi yang berdampak pada inklusivitas keuangan di masyarakat yang semakin luas.

\section{DAFTAR PUSTAKA}

A Sobarna, S Hambali, S Sutiswo, D Sunarsi. (2020). The influence learning used ABC run exercise on the sprint capabilities. Jurnal Konseling dan Pendidikan 8 (2), 67-71

A Sudarsono, D Sunarsi. (2020). Pengaruh Kualitas Pelayanan Dan Varian Produk Terhadap Keputusan Pembelian Pada Laboratorium Klinik Kimia FarmaBintaro. Value: Jurnal Manajemen dan Akuntansi 15 (1), 16-26

Azizah, S. N. (2014). Pengelolaan Unit Usaha Pesantren Berbasis Ekoproteksi, IX(1), 103-115.

Creswell, J. (2016). Research Design (Pendekatan Metode Kualitatif, Kuantitatif dan Campuran).

D Sunarsi. (2014). Pengaruh Gaya Kepemimpinan, Motivasi dan Disiplin Kerja Terhadap Kinerja Pendidik. Universitas Pamulang

Gumilar, I., Sunarsi, D. (2020). Comparison of financial performance in banking with high car and low car (Study of banks approved in the kompas 100 index for the period 2013-2017). International Journal of Psychosocial Rehabilitation. Volume 24 - Issue 7

Kadir, A. (2015). Pemberdayaan Santri di Pondok Pesantren Attarbiyatussakilah Kota Kendari. Al-Qalam, Vol. 21(No. 2), 221-234.

Kusdiyanto. (2008). Pengelolaan Dana Yayasan Pondok Pesantren Yatim Hajjah Patisah ( Komplek Masjid Patisah Pajang Surakarta ). Warta, Vol. II(No. 2), 
81-89.

Maddinsyah, A., Sunarsi, D., Hermawati, R., Pranoto. (2020). Analysis of location selection effect on the user decision that influcence the success of the service business of micro, small and medium enterprise (MSME) in bandung timur region. International Journal of Advanced Science and Technology. Vol. 29 No. 06

Madjid, N. (1998). Bilik-Bilik Pesantren: Sebuah Potret Perjalanan. Jakarta: Paramadina.

Miles, B.Matthew; Huberman, M. (2014). Analisis Data Kualitatif.

Priandhika, Rendri; Nafik, M. (2016). Pencapaian Kemandirian Operasional Melalui Pengelolaan Aset Di Pondok Pesantren Annuqayah. JurnalEkonomi Syariah Teori Dan Terapan, Vol 3(No. 7), 575-583.

Purwanti, P., Sarwani, S., \& Sunarsi, D. (2020). Pengaruh Inovasi Produk Dan Brand Awareness Terhadap Keputusan Pembelian Konsumen Pada Pt. Unilever Indonesia. Inovasi, 7(1), 24-31.

Rifqi, A. M. (2014). Strategi peningkatan dan pemanfaatan sumber pembiayaan mandiri di pondok pesantren. Manajemen Pendidikan, 24(No. 4), 325-328.

Sunarsi, D., \& Asmalah, L. (2018). Pelatihan Manajemen Pengembangan Diri Bagi Penerima Beasiswa RZIS UGM Dan Dompet Shalahuddin Jogjakarta. Jurnal Pengabdian Dharma Laksana, 1(1).

Sunarsi, D., \& Asmalah, L. (2018). Pelatihan Manajemen Pengembangan Diri Bagi Penerima Beasiswa RZIS UGM Dan Dompet Shalahuddin Jogjakarta. Jurnal Pengabdian Dharma Laksana, 1(1), 51-60.

Sunarsi, D., \& Erlangga, A. (2020). The Effect of Leadership Style and Work Environment on the Performance of Stationary Pump Operators in the Water Resources Office of West Jakarta City Administration. International Journal of Advances in Social and Economics, 2(3).

Sunarsi, D., Kustini, E., Lutfi, A. M., Fauzi, R. D., \& Noryani, N. (2019). Penyuluhan Wirausaha Home Industry Untuk Meningkatkan Ekonomi Keluarga Dengan Daur Ulang Barang Bekas. BAKTIMAS: Jurnal Pengabdian pada Masyarakat, 1(4), 188-193.

Sunarsi, D., Kusjono, G., \& Nuryana, I. (2019). Pelatihan Manajemen Penguasaan Kelas Dan Pembuatan Bahan Ajar Bagi Tenaga Pengajar Sukarela Taman Belajar Kreatif Mekarsari. Jurnal Pengabdian Dharma Laksana, 2(1), 41-44.

Suwanto, S. (2019). Pengaruh Disiplin Kerja Dan Motivasi Kerja Terhadap Kinerja Karyawan Pada Rumah Sakit Umum Tangerang Selatan. JENIUS, 3(1), 1623.

Suwanto, S. (2019). Pengaruh Gaya Kepemimpinan Dan Lingkungan Kerja Terhadap Kinerja Karyawan Unit Telesales Pada PT BFI Finance Indonesia Tbk. Jurnal Ekonomi Efektif, 1(2).

Yakin, N. (2014). Studi Kasus Pola Manajemen Pondok Pesantren Al-Raisiyah di Kota Mataram. Ulumuna, Vol. 18(No. 1). 